\title{
Suksesi Kepemimpinan dalam Partai Politik: (Studi atas Partai Golkar dan Partai Persatuan Pembangunan)
}

\author{
Jamaludin Ghafur dan M. Yasin al Arif \\ Fakultas Hukum Universitas Islam Indonesia \\ Jl. Taman Siswa 158 Yogyakarta \\ james.fhuii@gmail.com; yasinfhuii@gmail.com
}

Received: 9 Agustus 2017; Accepted: 11 Januari 2018; Published: 5 Juni 2018

DOI: 10.20885/iustum.vol24.iss4.art4

\begin{abstract}
This study aimed to examine and find out about the requirements and mechanisms for the election of Golkar and PPP candidates of leaders, as well as to evaluate the mechanisms and requirements of the leadership succession in Golkar and PPP in order to ensure a smooth process of leadership succession so as to avoid any leadership dualism. The problems of this study were (1) How are the mechanisms and requirements of the leadership succession in Golkar and PPP? (2) Are the mechanisms and requirements of the leadership succession in Golkar and PPP able to provide legal certainty to avoid leadership dualism? This was a normative legal research with statute approach. The data were secondary data consisting of primary, secondary, and tertiary legal materials. The findings showed that both Golkar and PPP have set in details the requirements and mechanisms of leadership succession in their Statutes and Bylaws. Therefore, seen from the legal-formal aspect, the Statutes and Bylaws of these parties are able to serve as the rule of the game in leadership succession. However, conflicts still occur because some party elites do not have adherence to the rules that leadership dualism is unavoidable.
\end{abstract}

Keywords: Political partiy; leadership succession

\section{Abstrak}

Penelitian ini bertujuan untuk mengkaji dan mengetahui persyaratan dan mekanisme pemilihan calon Ketua Partai Golkar dan PPP, sekaligus mengevaluasi mekanisme dan persyaratan suksesi kepemimpinan dalam Partai Golkar dan PPP agar dapat memberikan kelancaran dalam proses suksesi kepemimpinan guna menghindari terjadinya dualisme kepengurusan. Fokus penelitian ini adalah (1) Bagaimanakah mekanisme dan persyaratan suksesi kepemimpinan dalam Partai Golongan Karya dan Partai Persatuan Pembangunan? (2) Apakah mekanisme dan persyaratan suksesi kepemimpinan dalam Partai Golongan Karya dan Partai Persatuan Pembangunan tersebut sudah memberikan kepastian hukum guna menghindari terjadinya dualisme kepengurusan? Penelitian ini adalah yuridis normatif dengan pendekatan perundang-undangan (statute approach). Data yang digunakan adalah data sekunder yang terdiri atas bahan hukum primer, bahan hukum sekunder dan bahan hukum tersier. Hasil penelitian menunjukkan bahwa baik Partai Gokkar maupun PPP telah mengatur secara rinci persyaratan dan mekanisme suksesi kepemimpinan dalam Anggaran Dasar dan Anggaran Rumah Tangga Partai. Sehingga dari aspek legal-formal, AD/ART partai telah cukup memadai untuk dijadikan sebagai aturan main (rule of the game) dalam suksesi kepemimpinan. Namun demikian, perilaku sebagian elit partai yang tidak mau mematuhi aturan main tersebut telah menyebabkan lahirnya konflik. Sehingga dualisme kepengurusan partai pun tidak dapat dihindarkan.

Kata-kata Kunci: Partai politik; suksesi kepemimpinan 


\section{Pendahuluan}

Partai politik (parpol) memiliki andil yang besar dalam membangun dan menjaga stabilitas demokrasi. Sebab, partai politik merupakan salah satu pilar demokrasi yang paling berpengaruh dalam kehidupan berdemokrasi pada suatu negara. Sehingga dapat dikatakan bahwa negara tanpa partai politik tidaklah layak disebut negara demokrasi karena parpol adalah salah satu kelengkapan utama dari negara demokrasi. ${ }^{1}$

Berdasarkan Undang-Undang Nomor 2 Tahun 2008 Jo. Undang-Undang Nomor 2 Tahun 2011 tentang Partai Politik (UU Partai Politik), tujuan khusus dibentuknya partai politik adalah untuk meningkatkan partisipasi politik anggota dan masyarakat dalam rangka penyelenggaraan kegiatan politik dan pemerintahan. Tujuan ini sejatinya berangkat dari anggapan bahwa dengan membentuk wadah organisasi mereka bisa menyatukan orang-orang yang mempunyai pikiran serupa sehingga pikiran dan orientasi mereka bisa dikonsolidasikan. Dengan begitu pengaruh mereka bisa lebih besar dalam pembuatan dan pelaksanaan putusan. ${ }^{2}$ Karena dalam negara demokrasi, raktyatlah yang mempunyai kedaulatan tertinggi untuk mengatur negaranya dan melalui parpol rekrutmen terhadap rakyat untuk ditempatkan sebagai penyelenggara negara akan dilaksanakan.

Partai politik mempunyai posisi (status) dan peranan (role) yang sangat penting dalam setiap sistem demokrasi. Partai memainkan peran penghubung yang sangat strategis antara proses-proses pemerintahan dengan warga negara. Bahkan, para ahli politik dan ketatanegaraan berpendapat, partai politiklah yang sebetulnya menentukan demokrasi sebagaimana diungkapkan oleh Schattsheider (1942) "political parties created democracy". Oleh karena itu, partai politik merupakan pilar yang sangat penting untuk diperkuat derajat pelembagaannya (the degree of institutionalization) dalam setiap sistem politik yang demokratis. Bahkan oleh

${ }^{1}$ I Gede Made Matera, "Peran Partai Politik dalam Mewujudkan Demokrasi yang Santun dan Kesejahteraan Rakyat", Jurnal Sains dan Teknologi Vol. 10 No. 3 April 2011, hlm. 46

2 Miriam Budiardjo, Dasar-dasar Ilmu Politik, Gramedia Pustaka Utama, Jakarta, 2009, hlm. 403 
Schattscheider dikatakan pula, "modern democracy is unthinkable save in terms of the parties". 3

Pengaruh partai politik terhadap sistem demokrasi akan semakin jelas jika melihat fungsi-fungsi yang melekat padanya. Miriam Budiardjo menyebut empat fungsi partai politik: (i) komunikasi politik, (ii) sosialisai politik, (iii) rekrutmen politik, dan (iv) pengatur konflik. ${ }^{4}$ Mengingat pentingnya peran dan fungsi partai politik dalam sistem demokrasi - terlebih dalam sistem demokrasi perwakilan maka tidak salah jika dikatakan berfungsi dan bekerjanya kehidupan negara yang demokratis, sangat bergantung pada keberadaan partai politiknya. ${ }^{5}$ Namun sayangnya, sebagai sebuah institusi penyangga demokrasi yang strategis, perkembangan kelembagaan partai politik di Indonesia sangat memprihatinkan. Selain karena sebagian besar terkoyak oleh kasus-kasus korupsi dan perilaku tidak terpuji oleh kader-kadernya di parlemen, baik di Pusat maupun di Daerah. ${ }^{6}$ Partai politik juga sering dianggap sebagai instrumen demokrasi yang paling bermasalah. ${ }^{7}$

Untuk dapat menjalankan peran dan fungsinya dengan baik maka kelembagaan partai politik harus kuat, solid dan terjalinnya komunikasi yang baik antar pengurus. Jika hal ini tidak terlaksana dengan baik maka akan menimbulkan perpecahan dalam parpol dan hal inilah yang harus dihindari. Perpecahan parpol menjadi momok yang sangat menakutkan. Sebab jika hal ini terjadi tidak hanya akan berakibat buruk bagi kelangsungan kehidupan partai itu sendiri, namun juga akan membahayakan stabilitas demokrasi dan macetnya proses pemilu pada suatu negara karena tersendatnya fungsi rekrutmen politik oleh partai politik.

3 Jimly Asshidiqie, Pengantar Ilmu hukum Tata Negara Jilid 2, Sekretariat Jenderal Mahkamah Konstitusi, Jakarta, 2006, hlm. 153, lebih lanjut baca Schattschmeider, E.E, The Semisovereign People: A Realist's View of Democracy in America, The Dryden Press Hinsdale, Illionis, 1975

${ }^{4}$ Miriam Budiardjo, Dasar-dasar..., Op. Cit., hlm. 405-412

${ }^{5}$ Teguh Imansyah, "Regulasi Partai Politik dalam Mewujudkan Penguatan Peran dan Fungsi Kelembagaan Partai Politik”, Jurnal Rechtsvinding, Volume 1 Nomor 3, Desember 2012, hlm. 376

${ }^{6}$ Menurut hasil kajian kemitraan menunjukkan bahwa secara umum para politisi di DPR mempunyai empat cara dalam mengumpulkan dana, yaitu pertama, membuat kebijakan yang menguntungkan pihak tertentu; kedua, menyusun rencana proyek dan anggarannya dalam APBN yang kelak akan dikerjakan oleh pihak tertentu; Ketiga, menjadi calo tender proyek; dan keempat, meminta imbalan atas pemilihan jabatan publik atau pimpinan BUMN. Veri Junaidi, dkk, Anomali Kenangan Partai Politik Pengaturan dan Praktek, Kemitraan bagi Pembaruan Tata Pemerintahan, Jakarta, 2011, hlm. 7

${ }^{7}$ Moch. Nurhasim, "Kegagalan Modernisasi Partai Politik di Era Reformasi”, Jurnal Penelitian Politik, Vol. 10, No. 1, Juni 2013, LIPI, Jakarta, hlm. 27 
Di Indonesia, kekhawatiran perpecahan partai politik itu jamak terjadi. Kuatnya fragmentasi partai politik dan rendahnya tingkat pelembagaan menjadi cikal bakal pecahnya partai politik di Indonesia. ${ }^{8}$ Keadaan ini kerap kali terjadi ketika partai politik tersebut sedang melaksanakan suksesi pergantian kepengurusan. Gejala personalisasi masih sering menjadi penghambat dalam suksesi tersebut, sehingga berakibat pada terbentuknya dua kepengurusan dalam satu partai politik. Masing-masing kepengurusan menganggap kepengurusannya yang paling sah menurut AD/ART dan peraturan perundang-undangan partai politik.

Jika dilihat dari perspektif sejarah kepartaian di Indonesia, konflik dan perpecahan nampaknya sudah merupakan bagian yang tidak terpisahkan dari institusi parpol. Sebagaimana dikatakan oleh Lili Romli, bahwa: ${ }^{9}$

Semenjak jaman pergerakan hingga era reformasi, partai-partai politik selalu dilanda oleh konflik. Pada masa pergerakan, konflik melanda pada Partai Nasional Indonesia (PNI) sehingga melahirkan Parindra dan Partai Pendidikan Nasional. Begitu juga dengan Sarekat Islam (SI), yang pecah menjadi SI Merah dan SI Putih.

Konflik partai juga terjadi pada masa pasca kemerdekaan Indonesia. Untuk menyebut beberapa, konflik juga melanda Partai Masyumi. Para pendukung Masyumi ke luar satu persatu, mula-mula PSII, kemudian disusul oleh NU. Konflik juga terjadi di kalangan nasionalis, kita catat ada dua PIR, yaitu PIR Hazairin dan PIR Wongsonegoro.

Pada Orde Baru, dimana jumlah partai politik hanya dua, yakni Partai Persatuan Pembangunan (PPP) dan Partai Demokrasi Indonesia (PDI). Ternyata kedua partai hasil fusi ini selalu dilanda konflik tak berkesudahan. Konflik yang terjadi di PPP umumnya disebabkan karena perbedaan antar unsur pendukung, terutama antara NU dan MI. NU kemudian keluar dari PPP tahun 1984. Sementara di PDI akibat konflik yang terjadi menyebebabkan Megawati dan para pendukungnya keluar dari PDI dengan membentuk PDI Perjuangan.

Pada masa reformasi, "penyakit lama" itu ternyata masih ada dalam partaipartai politik kita. Kita selalu disuguhi oleh suasana konflik partai politik. Sebut saja misalnya konflik yang terjadi pada Golkar, sehingga kemudian melahirkan partai-partai baru, misalnya Partai MKGR, PKPI, dan PKPB. Konflik di PPP melahirkan Partai Persatuan (PP) dan PPP reformasi, yang kemudian menjadi Partai Bintang Reformasi (PBR). Konflik di PDIP

${ }^{8}$ Hanta Yuda, Presidensialisme Setengah Hati; Dari Dilema ke Kompromi, Gramedia Pustaka Utama, Jakarta, 2010, hlm. 125

${ }_{9}$ Lili Romli, "Mekanisme Penyelesaian Konflik Partai Politik", terdapat dalam http://lipi.go.id/berita/ mekanisme-penyelesaian-konflik-partai-politik/1394 diakses tanggal 2 Juni 2017. 
melahirkan Partai Nasional Banteng Kemerdekaan (PNBK), Partai Indonesia Tanah Airku (PITA), Partai Demokrasi Perjuangan Rakyat (PDPR), dan Partai Demokrasi Pembaharuan (PDP). Konflik di PBB melahirkan PAS dan PII. Konflik di PKB malahirkan PKD dan PKNU. Konflik di PD antara lain melahirkan Partai NKRI.

Namun, sejak 5 tahun belakangan, konflik tersebut semakin terbuka. Sebagai contoh, (saat penelitian ini dilakukan) dua partai politik di Indonesia tengah terjebak dalam prahara internal akibat dualisme kepemimpinan yaitu Partai Golongan Karya (Partai Golkar) dan Partai Persatuan Pembangunan (PPP) yang sama-sama memiliki dua ketua umum versi masing-masing kubu akibat konflik di internal partai. Tiap-tiap kubu menyerukan kepentingan pribadi golongan dengan pendapat yang berbeda-beda. ${ }^{10}$ Jalan islah masing-masing partai pun sudah diusahakan dengan berbagai mekanisme, namun sampai detik ini belum nampak tanda-tanda akan berakhirnya konflik dualisme kepengurusan tersebut.

Berangkat dari landasan dan permasalahan di atas, maka menarik untuk diteliti dan dikaji aturan main (rule of the game) tentang proses suksesi kepemimpinan partai politik karena saat pergantian kepemimpinan inilah perpecahan bahkan munculnya dualisme kepemimpinan ditubuh parpol sering terjadi.

\section{Rumusan Masalah}

Berangkat dari latar belakang di atas, maka rumusan masalah dalam penelitian ini adalah: pertama, bagaimanakah mekanisme dan persyaratan suksesi kepemimpinan dalam Partai Golongan Karya dan Partai Persatuan Pembangunan? Kedua, apakah mekanisme dan persyaratan suksesi kepemimpinan dalam Partai Golongan Karya dan Partai Persatuan Pembangunan tersebut sudah memberikan kepastian hukum guna menghindari terjadinya dualisme kepengurusan?

\section{Tujuan Penelitian}

Sebagai tindak lanjut dari rumusan masalah yang telah ditetapkan di atas, maka tujuan dilakukannya penelitian ini adalah: Pertama, untuk mengkaji dan

10 Djibril Muhammad, "Penyelesaian Perpecahan Partai Harus Ideologis", diakses dari http://www. republika.co.id/berita/nasional/politik/15/03/16/nlb15g-penyelesaian-perpecahan-partai-harus-ideologis pada tanggal 27 September 2015 
mengetahui persyaratan dan mekanisme pemilihan calon Ketua Partai Golongan Karya dan Partai Persatuan Pembangunan, dan Kedua, untuk mengkaji dan mengevaluasi mekanisme dan persyaratan suksesi kepemimpinan dalam Partai Golongan Karya dan Partai Persatuan Pembangunan agar dapat memberikan kelancaran dalam proses suksesi kepemimpinan guna menghindari terjadinya dualisme kepengurusan.

\section{Metode Penelitian}

Penelitian ini merupakan penelitian yuridis normatif yaitu penelitian yang difokuskan untuk mengkaji penerapan kaidah-kaidah atau norma-norma dalam hukum positif terhadap kasus-kasus konkrit. ${ }^{11}$ Pendekatan yang digunakan adalah pendekatan perundang-undangan (statute approach). Pendekatan ini dilakukan dengan menelaah semua peraturan perundang-undangan dan regulasi yang bersangkut paut dengan masalah hukum yang sedang diteliti. ${ }^{12}$ Penelitian ini menggunakan data sekunder yang terdiri atas bahan hukum primer, bahan hukum sekunder dan bahan hukum tersier. Bahan hukum primer dalam penelitian ini adalah UU Nomor 2 Tahun 2008 tentang Partai Politik sebagaimana telah diubah dengan Undang-Undang Nomor 2 Tahun 2011 tentang Partai Politik, bahan hukum sekunder yaitu berupa buku-buku literatur, jurnal-jurnal hukum dan hasil penelitian yang berkaitan dengan masalah yang diteliti, selain itu digunakan hasil wawancara untuk melengkapi kebutuhan data, wawancara ditujukan kepada Dewan Pimpinan Daerah (DPD) Partai Golkar dan PPP dan bahan hukum tersier berupa Kamus Besar Bahasa Indonesia (KBBI), kamus hukum, ensiklopedia dan lain-lain. Teknik pengumpulan bahan hukum dalam penelitian ini melalui studi pustaka dan studi dokumen, yaitu pengumpulan bahan hukum dengan mengkaji, menelaah dan mempelajari jurnal, hasil penelitian hukum dan mengkaji berbagai dokumen resmi institusional yang berupa peraturan perundang-undangan, risalah sidang dan literatur yang berhubungan dengan permasalahan penelitian. Bahan hukum yang berhubungan dengan masalah yang dibahas dipaparkan, disistematisasi kemudian dianalisis untuk mengintepretasikan hukum yang

${ }^{11}$ Johnny Ibrahim, Teori dan Metodologi Penelitian Hukum Normatif, Cet. II, Bayu Media, Malang, 2006, hlm. ${ }^{12}$ M. Syamsudin, Operasionalisasi Penelitian Hukum, Raja Grafindo, Jakarta, 2007, hlm. 58 
berlaku. Data yang diperoleh dalam penelitian ini akan disajikan dan dioalah secara kualitatif dengan langkah-langkah sebagai berikut: 1) data yang diperoleh dari penelitian diklasifikasikan sesuai dengan permasalahan dalam penelitian, 2) hasil kualifikasi data selanjutnya disistematisasikan, dan 3) data yang telah disistematisasikan kemudian dianalisis untuk dijadikan dasar dalam pengambilan keputusan.

\section{Hasil Penelitian dan Pembahasan}

\section{Mekanisme dan Persyaratan Suksesi Kepemimpinan dalam Partai Golongan Karya dan Partai Persatuan Pembangunan}

Pelembagaan partai politik dalam sistem demokrasi memainkan peranan penting dalam membangun stabilitas demokrasi suatu negara, oleh karenanya jika partai politik semakin terpolarisasi maka stabilitas demokrasi akan terguncang. Begitu juga dengan kesolidan dalam internal parpol dalam memajamen organisasi partai politik juga turut andil untuk membentuk demokrasi yang stabil. Pasal 1 angka 1 Undang-Undang Nomor 2 Tahun 2011 tentang Partai Politik, mendefinisikan partai politik sebagai organisasi yang bersifat nasional dan dibentuk oleh sekelompok warga negara Indonesia secara sukarela atas dasar kesamaan kehendak dan cita cita untuk memperjuangkan dan membela kepentingan politik anggota, masyarakat, bangsa dan negara, serta memelihara keutuhan Negara Kesatuan Republik Indonesia berdasarkan Pancasila dan Undang-Undang Dasar Negara Republik Indonesia 1945.

Namun demikian yang disebut organisasi partai politik, berbeda dengan organisasi kemasyarakat lainya, yaitu adanya ideologi politik dan yang selalu memperjuangkan terealisasinya ide mengenai masyarakat dan negara itu. ${ }^{13}$ Artinya sebagai sebuah organisasi, partai politiklah yang bertindak sebagai perantara dalam proses-proses pengambilan keputusan bernegara, yang menghubungkan antara warga negara dengan institusi-institusi kenegaraan. Menurut Robert Michaels dalam bukunya, Political Parties, A Sociolegal Study of the Oligarchial Tendencies of modern Democracy, menyatakan bahwa “... Organisasi ...

${ }^{13}$ Soenarko Setyodarmodjo, "Organisasi Partai Politik dan Demokrasi," Masyarakat, Kebudayaan dan Politik, Th XIII, No 1, Januari 2000, hlm. 89 
merupakan satu-satunya sarana ekonomi atau politik untuk membentuk kemauan kolektif" ${ }^{14}$

Sebagai sebuah organisasi, partai politik tidak lepas dari mekanisme suksesi kepemimpinan guna keberlanjutan kepengurusan sebuah partai. Melalui suksesi kepemimpinan inilah keberlanjutan partai politik sebagai penentu stabilisasi demokrasi dapat diberlangsungkan. Namun yang terjadi, tidak jarang partai politik yang sedang melakukan suksesi kepemimpinan malah mengalami perpecahan sehingga menimbulkan dualisme kepemimpinan. Hal inilah yang dialami oleh Partai Golkar dan PPP. Dalam bab ini akan diuraikan mengenai mekanisme dan persyaratan suksesi kepemimpinan Partai Golkar dan PPP guna mencari akar penyebab terjadinya dualisme kepemimpinan atau kepengurusan.

\section{Mekanisme dan Persyaratan Suksesi Kepemimpinan Partai Golkar}

Suksesi kepemimpinan dalam partai politik layaknya seperti organisasi pada umumnya yang pengaturan dan mekanismenya ditentukan dalam suatu Anggaran Dasar (AD) dan Anggaran Rumah Tangga (ART). Hal ini sebagaimana diamatkan oleh Pasal 22 UU Partai Politik yang menyatakaan bahwa: "Kepengurusan Partai Politik di setiap tingkatan dipilih secara demokratis melalui musyawarah sesuai dengan AD dan ART".

Menurut ketentuan Pasal 30 ayat (1) AD Partai Golkar, ada dua macam musyawarah yang dijadikan forum untuk melakukan suksesi kepemimpinan yaitu Musyawarah Nasional dan Musyawarah Nasional Luar Biasa. Adapun yang dimaksud Musyawarah Nasional adalah pemegang kekuasaan tertinggi Partai yang diadakan sekali dalam 5 tahun. Sedangkan Musyawarah Nasional Luar Biasa adalah Musyawarah Nasional yang diselenggarakan dalam keadaan luar biasa, diadakan atas permintaan dan/atau persetujuan sekurang-kurangnya 2/3 Dewan Pimpinan Daerah Provinsi. Cara yang digunakan untuk melakukan suksesi kepemimpinan dalam kondisi normal adalah melalui Musyawarah Nasional, sementara penyelenggaraan Musyawarah Nasional Luar Biasa hanya dapat diadakan dengan persyaratan-persyaratan khusus (tidak normal). Musyawarah

${ }^{14}$ Jimly Asshiddiqie, Kemerdekaan Berserikat Pembubaran Partai Politik dan Mabkamah Konstitusi, Sekretariat Jenderal dan Kepaniteraan Partai Politik, Jakarta, 2006, hlm. 54 
Nasional Luar Biasa merupakan forum musyawarah yang salah satunya untuk memilih ketua umum dalam kondisi darurat.

Suksesi kepemimpinan di dalam partai politik merupakan bentuk pergantian kepengurusan suatu partai politik secara umum, oleh karenanya sebagai tindak lanjut dari AD di atas, maka dalam ART Partai Golkar diatur lebih lanjut tentang beberapa persyaratan untuk menjadi pengurus partai, termasuk syarat-syarat menjadi ketua umum secara khusus.

Syarat-syarat dan ketentuan untuk menjadi pengurus partai secara umum diatur dalam Pasal 12 ayat (1) dan ayat (2) ART Partai Golkar. Sementara khusus persyaratan untuk menjadi ketua umum diatur dalam ayat (3) pada pasal yang sama, yaitu: (a) Pernah menjadi Pengurus Partai Golkar tingkat Pusat dan/atau sekurang-kurangnya pernah menjadi Pengurus Partai Golkar tingkat provinsi dan/atau pernah menjadi Pengurus Pusat Organisasi Pendiri dan yang didirikan selama 1 periode penuh, dan didukung oleh minimal 30\% Pemegang Hak Suara; (b) Aktif terus menerus menjadi anggota Partai Golkar sekurang-kurangnya 5 tahun dan tidak pernah menjadi anggota partai politik lain; (c) Pernah mengikuti pendidikan dan pelatihan dasar kader; (d) Memiliki prestasi, dedikasi, disiplin, loyalitas; dan tidak tercela; (e) Memiliki kapabilitas dan akseptabilitas; (f) Tidak pernah terlibat G 30 S PKI; (g) Bersedia meluangkan waktu dan sanggup bekerjasama secara kolektif dalam Partai Golkar.

Adapun terkait mekanisme pemilihan ketua umum, diatur lebih lanjut dalam Pedoman Kerja Komite Pemilihan. Di dalam pedoman kerja ini diatur mengenai tata cara penjaringan, pencalonan dan pemilihan ketua umum. Suksesi kepemimpinan Partai Golkar dimulai dari tahapan penjaringan. Berdasarkan ketentuan Pasal 4 peraturan pencalonan dan pemilihan ketua umum/ketua formatur dan anggota formatur Musyawarah Nasional Luar Biasa (Munaslub) Parta Golkar 2016, proses penjaringan dilakukan melalui (a) pendaftaran bakal calon, (b) sosialisasi dan kampanye di 5 zona, (c) debat publik, (d) verifikasi bakal calon dan (d) penilaian etik terhadap seluruh proses penjaringan. Selanjutnya pada tahap pencalonan, meliputi kegiatan-kegiatan (a) pembacaan nama-nama bakal calon ketua umum/bakal calon ketua formatur, (b) pengumuman hasil penilaian 
etik terhadap bakal calon ketua umum/bakal calon ketua formatur, (c) pemilihan calon ketua umum melalui proses pemungutan suara secara langsung, bebas, rahasia (tertutup) untuk memenuhi persyaratan minimal dukungan 30\% dari pemegang hak suara, dan (d) pemilihan anggota formatur. Terkait pemilihan ketua umum atau ketua formatur diatur dalam Pasal 5. Terdapat beberapa mekanisme ketentuan terkait pemilihan ketua umum. Di antaranya adalah (a) pemungutan suara, (b) pemilihan ketua umum/ketua formatur, dan (c) pemilihan anggota formatur.

\section{Mekanisme dan Persyaratan Suksesi Kepemimpinan PPP}

Sebagai hasil perjuangan fusi politik dari partai politik Islam dan pendiriannya juga bertepatan pada masa Orde Baru, PPP menjadi salah satu partai dari dua partai dan satu golongan karya yang diakui pada masa pemerintahan Soeharto tatkala itu. Walaupun pengakuan tersebut merupakan hasil fusi paksa yang disponsori pemerintah terhadap sembilan partai yang eksis dalam pemilu 1971, pemilihan umum pertama di bawah Orde Baru. ${ }^{15}$ Namun setidaknya PPP dapat dikatakan sebagai partai yang sudah memiliki banyak pengalaman sebagai peserta pemilu yaitu sejak Orde Baru.

Tidak jauh berbeda dengan organisasi partai politik yang lainnya, dalam melakukan suksesi kepemimpinan dilakukan sesuai dengan AD/ART partai politik. Sebagaimana diamanatkan oleh UU Partai Politik Pasal 23 ayat (1) "Pergantian kepengurusan Partai Politik di setiap tingkatan dilakukan sesuai dengan AD/ART".

Suksesi kepemimpinan di dalam tubuh PPP dilakukan melalui Muktamar. Sebagaimana tertuang dalam AD Pasal 51 ayat (1) disebutkan, Muktamar adalah musyawarah tingkat nasional yang memegang kekuasaan tertinggi PPP, diadakan 5 tahun sekali. Terdapat beberapa kewenangan dalam penyelenggaraan Muktamar, seperti disebutkan dalam ayat (3), yaitu Muktamar berwenang:

a. Menetapkan dan/atau mengubah anggaran dasar dan Anggaran Rumah Tangga;

b. Menilai laporan pertanggungjawaban DPP yang disampaikan oleh Pengurus Harian Partai;

${ }^{15}$ Denny Indrayana, Amandemen UUD 1945, Antara Mitos dan Pembongkaran, Mizan, Bandung, 2007, hlm. 
c. Menetapkan perjuangan partai;

d. Memilih dan/atau menetapkan Pengurus Harian DPP, Pimpinan Majelis Syari'ah DPP, Pimpinan Majelis Perimbangan PPP, Pimpinan Majelis Pakar DPP, serta Pimpinan Mahkamah Partai;

e. Menetapkan keputusan-keputusan lainnya yang dianggap perlu;

Di antara kewenangan yang telah dipaparkan di atas, pada poin d merupakan salah satu kewenangan Muktamar dalam proses pergantian kepengurusan atau suksesi kepemimpinan. Selain melalui Muktamar terdapat pula mekanisme untuk melakukan suksesi dalam kondisi darurat yaitu melalui Muktamar Luar Biasa. Sebagaimana disebutkan dalam Pasal 52 ayat (1) Anggaran Dasar, "Muktamar Luar Biasa dapat diadakan apabila Pengurus Harian DPP dalam keadaan tidak mampu melaksanakan tugas-tugasnya sebagaimana diamanatkan oleh Muktamar".

Selain itu, dalam ART terdapat beberapa persyaratan yang harus dipenuhi untuk menjadi pengurus pimpinan di semua tingkatkan. Dalam BAB III tentang Pimpinan, bagian pertama tentang persyaratan dan larangan, Pasal 5 ART disebutkan bahwa untuk dapat dipilih menjadi Anggota Pengurus Dewan Pimpinan di semua tingkatan harus memenuhi syarat:

a. Beriman dan bertaqwa kepada Allah SWT serta berakhlak mulia, memiliki prestasi, dedikasi, dan loyalitas yang tinggi terhadap PPP;

b. Telah menjadi Anggota PPP yang dibuktikan dengan Kartu Tanda Anggota;

c. Tidak sedang menjalani pidana berdasarkan putusan pengadilan yang telah memperoleh kekuatan hukum tetap;

d. Khusus untuk jabatan Ketua Umum dan Sekretaris Jenderal Pengurus Harian DPP harus pernah menjadi Pengurus DPP sekurang-kurangnya 1 (satu) masa bakti dan/atau sekurang-kurangnya 1 (satu) masa bakti pada kepengurusan 1 (satu) tingkat di bawahnya;

e. Khusus untuk jabatan Ketua dan Sekretaris Pengurus Harian DPW/DPC/PAC harus pernah menjadi Pengurus PPP. Apabila hal itu sulit dilaksanakan maka Ketua dan Sekretaris Pengurus Harian DPW/DPC/PAC harus pernah menjadi pengurus organisasi Islam, terutama organisasi pendiri PPP, sekurangkurangnya 1 (satu) masa bakti pada masing-masing tingkatannya dan/atau pada kepengurusan 1 (satu) tingkat di atas atau di bawahnya.

\section{Partai Golongan Karya}

Jika mengacu pada ketentuan dalam AD/ART Partai Golkar, maka ketentuan tentang suksesi kepemimpinan sudah sangat jelas dan tegas diatur baik 
persyaratan maupun mekanismenya. Namun demikian, kondisi ini ternyata tidak mampu menghindarkan terjadinya perpecahan di internal elit Partai Golkar itu sendiri. Hal ini terbukti dari adanya dua penyelenggaraan Musyawarah Nasional (Munas) yaitu Munas versi Bali dan Munas versi Ancol yang kemudian melahirkan kepengurusan ganda antara kubu Aburizal Bakrie (mewakili Munas Bali) dan Agung Laksono (mewakili Munas Ancol).

Menurut Djon Kibo salah seorang kader Partai Golkar dari DPD Yogyakarta, ada beberapa faktor yang menyebabkan terjadinya perpecahan di internal kepengurusan Partai Golkar. ${ }^{16}$ Pertama, banyaknya jumlah pengurus setelah Munas Riau menyebabkan terbengkalainya rapat pleno (jarang kuorum), sehingga minim sekali terlaksana. Padahal keputusan tertinggi diambil di rapat pleno tersebut. Pada akhirnya putusan-putusan penting organisasi seringkali diambil dari orang-orang di sekitar ketua umum saja yang kemudian dianggap sebagai keputusan organisasi.

Kedua, janji-janji Ketua Umum tatkala pemilihan di Riau tidak direalisasikan, seperti membangun gedung 24 lantai termasuk bantuan rutin partai kepada jajaran DPP 1 dan DPP 2 yang tradisinya selalu berjalan selama ini untuk membantu kepengurusan partai di daerah, pada kepemimpinan Abu Rizal Bakrie hanya berjalan diawal kepemimpinan dan pada 3 tahun terakhir tidak berjalan sama sekali.

Ketiga, partai berlambang beringin ini kalah diajang pemilihan legislatif yang seharusnya keluar menjadi pemenang. Ditambah lagi ketika Ketua Umum turun menjadi calon presiden kalah pada saat pemilihan dan bertolak mendukung Prabowo menjadi partai oposisi. Hal ini bertentangan dengan jati diri Partai Golkar sebagai partai pendukung pemerintah.

Jika diteliti lebih jauh, terjadinya dua Munas yang sekaligus menghasilkan dua kepemimpinan di tubuh golkar ini tidak terlepas dari perbedaan pendapat antara kelompok yang pro Aburizal Bakrie (Ical) dan kubu anti-Ical tentang pelaksanaan Munas. Jika mengacu pada AD/ART partai, memang ditegaskan bahwa masa kepengurusan untuk setiap periode dibatasi selama 5 tahun.

\footnotetext{
${ }^{16}$ Hasil Wawancara dengan Djon Kibo salah seorang kader partai DPD Provinsi DIY pada tanggal 31-052016 di kantor wilayah Partai Golkar Provinsi DIY.
} 
Mengingat Munas Pekanbaru Riau berakhir pada tanggal 8 Oktober 2009, berarti Munas Partai Golkar dilaksanakan selambat-lambatnya tanggal 8 Oktober 2014. Hanya saja, ada rekomendasi Munas Riau yang menyebutkan perpanjangan waktu kepengurusan sampai 2015. Kubu pro-Ical menginginkan pelaksanaan Munas dilakukan sesuai rekomendasi Munas Riau, yaitu sampai 2015. Sedangkan kubu anti Ical terus mengupayakan agar Munas Partai Golkar disesuaikan dengan AD Partai Golkar yaitu pelaksanaan munas digelar pada Oktober 2014. ${ }^{17}$

Keadaan semakin panas ketika perbedaan tafsir antara penganut AD Partai Golkar versus rekomendasi Munas Riau, disikapi dengan cara yang dianggap otoriter. DPP Partai Golkar di bawah Ical memutuskan untuk memberikan sanksi kepada pengurus DPP Partai Golkar yang mendesak Munas dilaksanakan sesuai dengan AD Partai Golkar. Tindakan yang dianggap otoriter itu dilakukan dengan mencopot dan menggeser sejumlah pengurus dari jabatannya. ${ }^{18}$

Berdasarkan hal di atas, maka akar persoalan yang menyebabkan terjadinya kepengurusan ganda di dalam Partai Golkar sebenarnya terletak perbedaan tafsir penyelenggaraan munas antara versi rekomendasi Munas Riau 2009 dan versi AD Partai. Berdasarkan Pasal 30 ayat (2) huruf a AD Partai Golkar memang diatur bahwa, "Musyawarah Nasional adalah pemegang kekuasaan tertinggi Partai yang diadakan sekali dalam 5 tahun". Itu artinya, berdasarkan ketentuan ini, Munas Riau 2009 yang memberi peluang perpanjangan 1 tahun kepengurusan DPP Partai Golkar sekilas memiliki dasar pijakan hukum karena apapun yang diputuskan dalam munas sebagai pemegang kekuasaan tertinggi Partai Golkar dapat mengambil keputusan apapun asalkan keputusan tersebut mendapatkan dukungan mayoritas minimal 50+1 suara. Namun demikian, seluruh keputusan apapun yang diputuskan dalam forum munas harus tetap dalam koridor hukum yang dalam konteks ini harus sesuai dengan AD/ART Partai Golkar.

Sekalipun dalam AD Partai Golkar tidak disebutkan secara eksplisit masa periode kepemimpinan, namun berdasarkan Pasal 30 huruf (a) dan huruf (b) angka iv dapat disimpulkan bahwa periode kepemimpinan Partai Golkar adalah 5 tahun.

${ }^{17}$ Mulawarman, Konflik Golkar: Siapa Yang Bermain?, Agatama Press, Jakarta, 2016, hlm. 30-31

18 Ibid., hlm. 35 
Pasal tersebut berbunyi: (a) Musyawarah Nasional adalah pemegang kekuasaan tertinggi Partai yang diadakan sekali dalam 5 (lima) tahun, (b) Musyawarah Nasional berwenang : (iv) memilih dan menetapkan Ketua Umum. Dengan demikian, sangat jelas bahwa keputusan Munas Riau 2009 yang memberi peluang kepada pemimpin Partai Golkar untuk dapat memperpanjang masa jabatannya 1 (satu) tahun adalah bertentangan dengan AD/ART Partai Golkar sehingga dengan demikian seharusnya keputusan tersebut batal demi hukum. Pengabaian pada aturan main AD/ART Partai Golkar inilah yang kemudian memicu konflik di internal Partai Golkar yang berujung pada munculnya dualisme kepemimpinan antara Aburizal Bakrie yang terpilih berdasarkan hasil Munas Bali dan Agung Laksono yang terpilih berdasarkan hasil Munas Ancol.

Konflik kepengurusan ganda yang terjadi ditubuh Partai Golkar sebenarnya telah diberikan jalan keluar oleh UU Partai Politik. Sepanjang mengenai mekanisme penyelesaian perselisihan partai politik telah diatur di dalam UU Partai Politik pada Pasal 32 dan Pasal 33. Sesuai amanat Pasal 32 ayat (1) UU Partai Politik menyatakan bahwa Perselisihan Partai Politik diselesaikan oleh internal Partai Politik sebagaimana diatur di dalam AD/ART, maka ART Partai Golkar pada Bab XV Pasal 47 ayat (2) telah mengatur hal ini yaitu penyelesaian perselisihan hukum melalui, (i) musyawarah, (ii) arbitrase dan (iii) pengadilan.

Kedua belah pihak sebenarnya telah mencoba untuk menyelesaikan konflik di internal Partai Golkar sesuai dengan amanat peraturan perundang-undangan dan AD/ART yang berlaku. Misalnya, Partai Golkar telah membentuk Mahkamah Partai. Hal ini sesuai dengan Pasal 32 UU Partai Politik bahwa yang berwenang menyelesaikan perselisihan internal partai adalah Mahkamah Partai. Namun demikian, putusan Mahkamah Partai Golkar (MPG) tidak mencapai kesepakatan sehingga penyelesaian perselisihan partai harus diselesaikan melalui Pengadilan Negeri sebagaimana amanat Pasal 33 UU Partai Politik yang berbunyi “dalam hal penyelesaian perselisihan sebagaimana dimaksud dalam Pasal 32 tidak tercapai, penyelesaian perselisihan dilakukan melalui pengadilan negeri".

Jalan musyawarah yang pada awalnya diharapkan dapat mengakhiri konflik di internal Partai Golkar tidak membuat hasil sehingga perseteruan antara kubu pro-Ical dan anti-Ical memuncak pada pelaksanaan Munas Bali yang memilih Ical 
sebagai Ketua Umum Partai Golkar secara aklamasi, dan Munas Ancol di mana Agung Laksono terpilih sebagai Ketua Umum Partai Golkar. Kedua belah pihak kemudian sama-sama mengajukan pendaftaran susunan pengurus Partai Golkar yang baru ke kemenkum HAM. ${ }^{19}$

Namun melalui SK Menkum HAM No: M.HH-01.AH.11.01 tahun 2015, Kemenkumham mengesahkan kepengurusan umum DPP Partai Golkar versi Munas Ancol. Menanggapi hal ini, kubu Ical mengajukan gugatan ke Pengadilan Tinggi Tata Usaha Negara (PTUN) pada 23 Maret 2015 dan mengabulkan gugatannya. Namun demikian, putusan PTUN ini masih belum bisa menuntaskan kisruh Golkar karena pengurus Partai Golkar versi Munas Ancol (Agung Laksono) langsung mengajukan banding. Setelah ditunggu, akhirnya datanglah putusan PTTUN terkait banding kubu Munas Ancol. Dan ternyata putusan PTTUN itu memenangkan kubu Munas Ancol dengan mengabulkan banding kubu Agung Laksono. Menanggapi putusan ini, kubu Ical mengajukan kasasi ke Mahkamah Agung (MA). Adapun putusan MA yaitu menerima kasasi yang diajukan Ketua Umum Partai Golkar hasil Munas Bali (Aburizal Bakrie). Majelis hakim dalam persidangannya memutuskan untuk kembali ke putusan PTUN. Pertimbangan hukum Mahkamah Agung dalam Putusan Nomor 490 K/TUN/ 2015 menyatakan bahwa:

“Tindakan hukum Tergugat menerbitkan objek sengketa bertentangan dengan asas-asas umum pemerintahan yang baik, terutama asas kecermatan dan kehati-hatian, karena seharusnya Tergugat pada waktu mengambil keputusan terlebih dahulu mencari gambaran yang jelas mengenai fakta yang relevan dan semua kepentingan pihak ketiga yang tersangkut. Dalam sengketa a quo terbukti masih terdapat perselisihan keabsahan perubahan susunan kepengurusan Dewan Pimpinan Pusat Partai Golkar, oleh karena itu seharusnya Tergugat tidak sampai pada penerbitan keputusan objek sengketa;"20

${ }_{19}$ Dalam perspektif Ted Robert, Gurr konflik akan terjadi karena ada beberapa pihak yang biasanya cenderung menjalankan perilaku koersif untuk menghadapi dan menghancurkan "sang musuh". Ted Robert Gurr (ed), Hand Book of Political Conflict: Theory and Research, The Free Press, New York, 1980, hlm. 2

${ }^{20}$ Dewi Rizki Amylia dan Hananto Widodo, “Tinjauan Yuridis Pelaksanaan Pencabutan SK Menkumham Nomor: M.HH-01.AH.11.01 tentang Pengesahan Perubahan Ad/Art Serta Komposisi Dan Personalia DPP Partai Golkar”, hlm. 4, terdapat dalam http://jurnalmahasiswa.unesa.ac.id/article/21173/43/article.pdf., diakses tanggal 27 Mei 2017 
Selanjutnya menteri Hukum dan HAM Yasonna Laoly, pada 30 Desember 2015, resmi menandatangani surat keputusan tentang pencabutan kepengurusan Golkar hasil Munas Ancol. Namun pencabutan SK tersebut tidak disertai pengesahan kubu Bali sehingga tidak ada kepengurusan Partai Golkar yang sah. Sikap Menkumham yang hanya membatalkan SK kepengurusan Partai Golkar Munas Ancol dan tidak mengakui kepengurusan Partai Golkar Munas Bali telah menimbulkan kegaduhan tersendiri. Pasalnya, sikap Menkumham ini dianggap sebagai intervensi dan keberpihakan pemerintah terhadap salah satu pihak. Artinya, Menkumham tidak bersikap netral namun lebih condong berpihak pada pengurus Partai Golkar hasil Munas Ancol.

Terlepas dari persoalan perbedaan tafsir tentang penyelenggaran Munas yang menjadi penyebab awal munculnya konflik internal di Partai Golkar, Siti Zuhroh berpendapat bahwa secara sosiologis konflik berulang yang terjadi di Partai Golkar antara lain disebabkan oleh panjangnya antrian regenerasi dalam Golkar. Hingga saat ini generasi Orde Baru masih mendominasi. Ini menyebabkan kesumpekan dan kegaduhan. Regenerasi seolah mampat. Kesadaran dari generasi tua untuk menyerahkan sirkulasi kepemimpinan ke generasi berikut merupakan kebutuhan. Aturan tentang kesuksesan kepemimpinan juga perlu dibuat secara terukur. Juga soal gizi, penggunaan politik uang dalam munas yang banyak menimbulkan kontroversi. Isu ini, bahkan, tak hanya menimbulkan pro dan kontra di internal Golkar, tapi juga ikut disorot tajam oleh publik. ${ }^{21}$

\section{Partai Persatuan Pembangunan}

Persyaratan tentang kepengurusan DPP PPP dan persyaratan untuk menjadi ketua umum secara khusus sebenarnya telah diatur secara baik dalam AD/ART PPP. Pasal 5 ART menyebutkan bahwa untuk dapat dipilih menjadi Anggota Pengurus Dewan Pimpinan di semua tingkatan harus memenuhi syarat:

a. Beriman dan bertaqwa kepada Allah SWT serta berakhlak mulia, memiliki prestasi, dedikasi, dan loyalitas yang tinggi terhadap PPP;

b. Telah menjadi Anggota PPP yang dibuktikan dengan Kartu Tanda Anggota;

c. Tidak sedang menjalani pidana berdasarkan putusan pengadilan yang telah memperoleh kekuatan hukum tetap;

${ }^{21}$ Siti Zuhroh, Pengantar, dalam Mulawarman, Op., Cit., hlm. xvi 
d. Khusus untuk jabatan Ketua Umum dan Sekretaris Jenderal Pengurus Harian DPP harus pernah menjadi Pengurus DPP sekurang-kurangnya 1 (satu) masa bakti dan/atau sekurang-kurangnya 1 (satu) masa bakti pada kepengurusan 1 (satu) tingkat di bawahnya;

e. Khusus untuk jabatan Ketua dan Sekretaris Pengurus Harian DPW/DPC/PAC harus pernah menjadi Pengurus PPP. Apabila hal itu sulit dilaksanakan maka Ketua dan Sekretaris Pengurus Harian DPW/DPC/PAC harus pernah menjadi pengurus organisasi Islam, terutama organisasi pendiri PPP, sekurangkurangnya 1 (satu) masa bakti pada masing-masing tingkatannya dan/atau pada kepengurusan 1 (satu) tingkat di atas atau di bawahnya.

Adapun forum pemilihan (suksesi) Ketua Umum dilakukan melalui musyawarah nasional yang dilaksanakan setiap 5 tahun sekali. Dalam kasus-kasus tertentu yang dikualifikasi sebagai keadaan darurat, tersedia mekanisme muktamar luar biasa. Hal ini menandakan bahwa secara aturan, suksesi kepemimpinan di PPP relatif tidak ada masalah dan telah mencerminkan kepastian hukum karena baik persyaratan maupun mekanismenya telah diatur sedemikian rupa.

Bila diamati secara seksama, munculnya konflik yang terjadi di tubuh PPP juga hampir mirip dengan apa yang terjadi di dalam Partai Golkar yaitu bukan disebabkan oleh tidak jelasnya aturan tentang persyaratan dan mekanisme suksesi kepemimpinan, namun dimulai dari konflik antar pribadi elit. Jika ditelusuri lebih jauh, ada persamaan sekaligus perbedaan pemicu konflik yang terjadi di Golkar dan PPP. Persamaannya setidaknya meliputi dua hal: Pertama, pilihan dukungan dalam pilpres 2014. Partai Golkar di bawah kepemimpinan Aburizal Bakrie dan PPP di bawah komando Suryadharma Ali sama-sama mendeklarasikan dukungannya kepada pasangan Prabowo Subianto dan Hatta Rajasa. Keputusan ini memicu pertentangan oleh sebagian elit partai yang menginginkan agar PPP mendukung pasangan calon Joko Widodo dan Jusuf Kalla, sementara sebagian elit partai golkar menginginkan agar mengusung kader sendiri. Kedua, adanya pemecatan secara sewenang-wenang terhadap para kader yang dianggap tidak sejalan dengan ketua umum.

Adapun perbedaannya, unsur utama yang menyulut perpecahan di internal PPP adalah berkaitan dengan pernyataan dukungan sepihak dari Suryadharma Ali 
selaku ketua PPP kepada calon presiden dan wakil presiden Prabowo Subianto dan Hatta Rajasa. ${ }^{22}$ Selain itu, penetapan status tersangka oleh KPK terhadap Suryadharma Ali juga semakin memperkeruh keadaan karena sebagian elit menginginkan adanya pergantian kepemimpinan namun hal ini mendapat penolakan dari para loyalis Suryadharma Ali. ${ }^{23}$

Sementara faktor utama konflik Partai Golkar adalah perbedaan pandangan para elit partai tentang pelaksanaan Munas. Golongan pro-Ical menginginkan Munas Golkar dilaksanakan sesuai amanat Munas Riau 2009 yaitu pada 2015, sementara kubu anti-Ical yang dimotori oleh Agung Laksono menginginkan munas dilaksanakan sesuai AD/ART partai yaitu akhir 2014.

Kendati pemecatan terhadap pihak-pihak yang berseberangan dengan ketua umum bukan merupakan pemicu utama dalam konflik PPP, namun perlu disadari bahwa pemecatan ini merupakan faktor yang mempercepat munculnya konflik yang lebih besar karena pihak-pihak yang tersingkirkan dalam kepengurusan partai akan mengkonsolidasi diri untuk melakukan perlawanan. Oleh karenanya, agar hal ini tidak terulang kembali di masa yang akan datang, atau setidaktidaknya untuk mengurangi intensitas terjadi konflik, sudah seharusnya dalam $\mathrm{AD} / \mathrm{ART}$ atau peraturan partai mengatur secara jelas tentang alasan-alasan dan prosedur pemecatan anggota dan pengurus partai. Sehingga, alasan pemecatan tidak semata-mata didasarkan pada subjektifitas ketua umum partai tetapi berdasarkan penilaian yang objektif dan terukur. Begitu juga pelengseran/pemberhentian terhadap ketua umum partai juga dapat dilakukan sesuai prosedur yang berlaku dengan alasan-alasan yang juga dapat dipertanggungjawabkan. ${ }^{24}$

${ }^{22}$ Keputusan Suryadharma yang menghadiri kampanye terbuka Prabowo dinilai 27 Dewan Pimpinan Wilayah (DPW) melanggar kesepakatan partai dalam Mukernas II. Dalam Mukernas II PPP di Bandung, PPP akan menjalin komunikasi politik dengan delapan bakal capres yang ada saat itu. Dalam dalam bursa capres PPP itu, tidak ada nama Prabowo. Akibat keputusan sepihak Suryadharma tersebut, DPP PPP menggelar rapat yang dikabarkan akan terjadi islah antara Suryadharma dengan kelompok yang tidak setuju dengan keputusan dukungannya ke Prabowo. Namun, Suryadharma justru mengaku memecat Wakil Ketua Umum Suharso Monoarfa dan beberapa Ketua DPD PPP yang dianggap Suryadharma berencana memakzulkan dirinya. Konflik panas di internal PPP pun mulai terjadi. Terdapat dalam http://news.metrotvnews.com/read/2014/09/13/290975/awalperseteruan-panas-ppp, diakses tanggal 27 Mei 2017

"23 Ade Hikmatul Fauziah, "Sikap Politik Partai Persatuan Pembanguan dalam Suksesi Kepemimpinan Negara Pada Pemilu 2014”, hlm. 31-32. Terdapat dalam http://repository.uinjkt.ac.id/dspace/ bitstream/123456789/31365/1/Ade\%20Hikmatul\%20Fauziah.pdf, diakses tanggal 26 Mei 2017

${ }^{24}$ Konflik panas PPP mencapai puncaknya pada pemecatan Suryadharma Ali sebagai Ketum PPP saat Rapat Harian DPP PPP pada Rabu (10/9/2014) lalu. Sekjen PPP Romahurmuziy mengatakan keputusan itu 
Sama dengan apa yang telah dilakukan oleh Partai Golkar, dalam menyelesaikan konflik internal, PPP juga telah berusaha untuk menyelesaikan persoalan ini melalui Mahkamah Partai. Mahkamah Partai PPP telah menggelar sidang dan membuat keputusan yang tertuang di dalam putusan final Mahkamah Partai atas perkara internal partai nomor 49/PIP/MP-DPP.PPP/2014.

Namun demikian, putusan Mahkamah Partai tersebut tidak dipatuhi oleh para pihak yang bersengketa sehingga hasilnya-pun tidak dapat menyelesaikan konflik yang ada. Selain itu, adanya intervensi politik dari Menkumham yang lebih berpihak kepada salah satu kubu yaitu dengan mengesahkan kepengurusan Romahurmuziy telah menyebabkan konflik PPP semakin rumit. Pengakuan sepihak pemerintah terhadap DPP PPP kepengurusan Romahurmuzy tertuang dalam Surat Keputusan Menteri Hukum dan HAM RI Nomor M.HH-07.AH.11.01 Tahun 2014 tentang Pengesahan Perubahan Susunan Kepengurusan DPP PPP. Hal ini mendorong kubu Suryadharma Ali mengajukan gugatan atas SK Menkumham tersebut ke PTUN dan sekaligus mengajukan gugatan perkara khusus Partai Politik ke Pengadilan Negeri.

Kedua gugatan tersebut telah sampai ke Mahkamah Agung dengan putusan sebagai berikut: Putusan Mahkamah Agung Nomor 504 K/TUN/2015 atas kasasi Putusan PTUN Jakarta yang berbunyi:25

\section{Mengadili Sendiri}

Dalam Eksepsi:

- Menyatakan eksepsi Tergugat dan Para Tergugat Intervensi tidak diterima untuk seluruhnya;

Dalam Pokok Sengketa:

1. Mengabulkan gugatan Para Penggugat untuk seluruhnya;

2. Menyatakan batal Surat Keputusan Menteri Hukum dan Hak Asasi Manusia Nomor M.HH-07.AH.11.01 Tahun 2014, tanggal 28 Oktober 2014

\footnotetext{
diambil karena Suryadharma sudah ditetapkan tersangka kasus korupsi oleh KPK dan melanggar beberapa aturan dalam AD/ART partai. Keputusan ini didukung 28 DPW PPP. Sebagai penggantinya, Waketum DPP PPP, Emron Pangkapi ditunjuk sebagai pelaksana tugas (Plt) Ketum PPP. Suryadharma Ali menegaskan pemberhentian dirinya sebagai Ketum PPP tidak sah. Menurutnya, pemberhentian itu sama sekali tak memiliki dasar. Itu ilegal, karena dia adalah ketua umum yang satu-satunya dipilih dalam muktamar untuk memimpin pada 2011-2015. Seakan geram dengan pemecatan terhadap dirinya, Suryadharma pun balik memecat belasan kader dari jabatan pengurus harian DPP PPP 2011-2015. Suryadharma menilai kader-kader tersebut membelot dan melakukan pelanggaran berat tidak mengikuti AD/RT partai. Terdapat dalam http://news.metrotvnews.com/read/2014/09/13/290975/awalperseteruan-panas-ppp, diakses tanggal 27 Mei 2017

25 Ahmad Gelora Mahardika, "Penghapusan Badan Hukum Partai Politik Sebagai Pencegahan Intervensi Pemerintah terhadap Partai Politik", Jurnal Etika \& Pemilu, Vol. 2, Nomor 2, Juni 2016, hlm. 21
} 
tentang Pengesahan Perubahan Susunan Kepengurusan Dewan Pimpinan Pusat Partai Persatuan Pembangunan;

3. Mewajibkan Tergugat untuk mencabut Surat Keputusan Menteri Hukum dan Hak Asasi Manusia Nomor M.HH-07.AH.11.01 Tahun 2014, tanggal 28 Oktober 2014 tentang Pengesahan Perubahan Susunan Kepengurusan Dewan Pimpinan Pusat Partai Persatuan Pembangunan Pembangunan.

Sementara itu terdapat pula Putusan Mahkamah Agung Nomor: 601 K/Pdt.Sus.Parpol/2015 atas kasasi Putusan PN Jakarta Pusat yang berbunyi: ${ }^{26}$

1. Mengabulkan gugatan Penggugat untuk sebagian;

2. Menyatakan susunan kepengurusan PPP hasil Muktamar VIII PPP pada tanggal 30 Oktober sampai 2 November 2014 di Jakarta sebagaimana ternyata dalam Akta Pernyataan Ketetapan Muktamar VIII Partai Persatuan Pembangunan pada tanggal 30 Oktober sampai 2 November 2014 di Jakarta mengenai susunan personalia Pengurus Dewan Pimpinan Pusat Partai Persatuan Pembangunan masa bakti Periode 2014 sampai 2019 Nomor 17 tanggal 7 November 2014 yang dibuat dihadapan H. Teddy Anwar, S.H., SpN. Notaris di Jakarta merupakan susunan kepengurusan PPP yang sah;

3. Menyatakan susunan kepengurusan hasil Muktamar VIII PPP di Surabaya pada tanggal 15 - 18 Oktober 2014 tidak sah dan batal demi hukum dengan segala akibat hukumnya;

Berdasarkan putusan MA di atas, seharusnya Pemerintah melalui Menteri Hukum dan HAM RI segera mengesahkan kepengurusan DPP PPP dengan pimpinan Djan Faridz hasil Munas di Jakarta, namun yang terjadi di lapangan berbeda dengan putusan Mahkamah Agung. Menteri Hukum dan HAM RI justru mengembalikan kepengurusan DPP PPP ke kepengurusan sebelum adanya SK Menkumham yang mengesahkan kepengurusan DPP PPP Romahurmuzy yaitu dengan mengeluarkan Surat Keputusan Menteri Hukum dan HAM RI Nomor M.HH-03.AH.11.01 Tahun 2016 tanggal 17 Februari 2016 tentang Pengesahan Kembali Susunan Personalia Dewan Pimpinan Pusat Partai Persatuan Pembangunan Hasil Muktamar Bandung 2011.

Untuk lebih memahami perbedaan dan persamaan faktor yang menyebabkan terjadinya konflik internal yang berujung pada terbentuknya dualisme kepengurusan di PPP dan Partai Golkar, berikut kami sajikan dalam bentuk tabel: 
Tabel

Persamaan dan Perbedaan Faktor Penyebab Konflik Internal PPP dan Golkar

\begin{tabular}{|c|c|c|}
\hline & Golkar & PPP \\
\hline Persamaan & \multicolumn{2}{|c|}{$\begin{array}{l}\text { 1. Mendeklarasikan dukungan kepada pasangan Prabowo Subianto } \\
\text { dan Hatta Rajasa. } \\
\text { 2. Pemecatan sewenang-wenang kepada para kader yang dianggap } \\
\text { tidak sejalan dengan kebijakan ketua umum. } \\
\text { 3. Penyelesaian konflik melalui Mahkamah partai, namun } \\
\text { mekanisme ini tidak menyelesaikan konflik sehingga berlanjut ke } \\
\text { Pengadilan. }\end{array}$} \\
\hline Perbedaan & $\begin{array}{l}\text { Faktor utama konflik Partai } \\
\text { Golkar adalah perbedaan } \\
\text { pandangan para elit partai } \\
\text { tentang pelaksanaan munas. }\end{array}$ & $\begin{array}{l}\text { Unsur utama yang menyulut } \\
\text { perpecahan di internal PPP } \\
\text { adalah berkaitan dengan } \\
\text { pernyataan dukungan sepihak } \\
\text { dari Suryadharma Ali selaku } \\
\text { ketua PPP kepada calon } \\
\text { presiden dan wakil presiden } \\
\text { Prabowo Subianto dan Hatta } \\
\text { Rajasa dan penetapan status } \\
\text { tersangka oleh KPK terhadap } \\
\text { Suryadharma Ali }\end{array}$ \\
\hline
\end{tabular}

\section{Penutup}

Berangkat dari hasil penelitian yang telah diuraikan di atas, maka dapat disimpulkan, pertama, berdasarkan ketentuan dalam AD Partai Golkar dan PPP, suksesi kepemimpinan dapat dilakukan melalui dua pintu, yaitu Musyawarah Nasional atau Mukatamar yang dilaksanakan setiap 5 tahun dan Musyawarah Nasiona Luar Biasa atau Muktamar Luar Biasa yang hanya dapat diadakan dalam kondisi darurat dengan syarat-syarat yang sudah ditetapkan dalam AD/ART masing-masing partai.

Adapun persyaratan untuk menjadi Ketua Umum Partai Golkar adalah sebagai berikut: (i) Pernah menjadi Pengurus Partai Golkar tingkat Pusat dan/atau sekurang-kurangnya pernah menjadi Pengurus Partai Golkar tingkat provinsi dan/atau pernah menjadi Pengurus Pusat Organisasi Pendiri; (ii) Aktif terus menerus menjadi anggota Partai Golkar sekurang-kurangnya 5 tahun; (iii) Pernah mengikuti pendidikan dan pelatihan dasar kader; (iv) Memiliki prestasi, dedikasi, disiplin, loyalitas; dan tidak tercela; (v) Memiliki kapabilitas dan akseptabilitas; (vi) 
Tidak pernah terlibat G 30 S PKI; (vii) Bersedia meluangkan waktu dan sanggup bekerjasama secara kolektif dalam Partai Golkar.

Sementara syarat yang harus dipenuhi untuk menjadi ketua umum PPP adalah: (i) Beriman dan bertaqwa kepada Allah SWT serta berakhlak mulia, memiliki prestasi, dedikasi, dan loyalitas yang tinggi terhadap PPP; (ii) Telah menjadi Anggota PPP yang dibuktikan dengan Kartu Tanda Anggota; (iii) Tidak sedang menjalani pidana berdasarkan putusan pengadilan yang telah memperoleh kekuatan hukum tetap; (iv) pernah menjadi Pengurus DPP sekurang-kurangnya 1 (satu) masa bakti dan/atau sekurang-kurangnya 1 masa bakti pada kepengurusan 1 (satu) tingkat di bawahnya.

Kedua, secara umum, pengaturan tentang persyaratan dan mekanisme suksesi kepemimpinan dalam Partai Golkar dan PPP sudah memenuhi aspek kepastian hukum. Perpecahan atau konflik internal yang dialami oleh kedua parpol ini lebih disebabkan oleh: (1) tidak dipatuhinya peraturan dalam AD/ ART masing-masing parpol oleh sebagian elit parpol terutama dalam pelaksanaan muktamar sebagai suatu forum pergantian kepemimpinan. (2) Terjadinya pemecatan secara arogan oleh Ketua Parpol terhadap kader-kader yang berseberangan pandangan politik dengan dirinya tanpa melalui prosedur yang demokratis. (3) Adanya intervensi pemerintah dalam hal ini Kementerian Hukum dan HAM yang cenderung mengesahkan kepengurusan pihak yang pro terhadap pemerintah sementara enggan untuk mengakui kepengurusan pihak yang beroposisi dengan pemerintah sekalipun pihak ini telah memiliki dasar hokum yang kuat dari pengadilan.

Adapun hasil penelitian yang telah diuraikan di atas penulis dapat memberikan sarana. Pertama, kader partai harus mematuhi peraturan dalam AD/ART yang sudah menjadi pedoman dasar pelaksanaan organisasi dan memberikan sanksi yang tegas terhadap kader yang tidak mematuhi AD/ART dalam penyelenggaraan suksesi kepemimpinan. Kedua, perlu adanya kedewasan seluruh elit parpol untuk menjadikan hukum sebagai panglima dalam mengelola parpol sehingga keputusan apapun yang akan dijalankan mestilah memperhatikan aturan main yang ada baik yang tertuang dalam peraturan perundanganundangan negara maupun peraturan internal AD/ART partai. Sementara di pihak pemerintah (Kemenkumham), hendaknya tidak mengeluarkan SK penetapan 
kepengurusan yang sah terhadap parpol yang masih mengalami konflik internal sebelum perpecahan partai politik selesai baik melalui musyawarah internal partai maupun dengan hasil keputusan pengadilan yang berkekuatan hukum tetap (inkracht van gewijsde)

\section{Daftar Pustaka}

\section{Buku}

Asshidiqie, Jimly, Pengantar Ilmu Hukum Tata Negara Jilid 2, Sekretariat Jenderal Mahkamah Konstitusi, Jakarta, 2006.

Kemerdekaan Berserikat Pembubaran Partai Politik dan Mahkamah Konstitusi, Konstitusi Pres, Jakarta, 2005.

Budiardjo, Miriam, Dasar-dasar Ilmu Politik, Gramedia Pustaka Utama, Jakarta, 2009.

Gurr, Ted Robert (ed), Hand Book of Political Conflict: Theory and Research, The Free Press, New York, 1980.

Yuda, Hanta Presidensialisme Setengah Hati Dari Dilema ke Kompromi, Gramedia Pustaka Utama, Jakarta, 2010.

Syamsudin, M. Operasionalisasi Penelitian Hukum, Raja Grafindo, Jakarta, 2007.

Mulawarman, Konflik Golkar: Siapa Yang Bermain? Agatama Press, Jakarta, 2016.

\section{Jurnal}

Imansyah, Teguh "Regulasi Partai Politik dalam Mewujudkan Penguatan Peran dan Fungsi Kelembagaan Partai Politik", Jurnal Rechtsvinding, Volume 1 Nomor 3, Desember 2012.

Mahardika, Ahmad Gelora, “Penghapusan Badan Hukum Partai Politik Sebagai Pencegahan Intervensi Pemerintah terhadap Partai Politik", Jurnal Etika $\mathcal{E}$ Pemilu, Vol. 2, Nomor 2, Juni 2016.

Matera, I Gede Made, "Peran Partai Politik dalam Mewujudkan Demokrasi yang Santun dan Kesejahteraan Rakyat", Jurnal Sains dan Teknologi, Vol. 10, No. 3 April 2011.

Nurhasim, Moch. “Kegagalan Modernisasi Partai Politik di Era Reformasi”, Jurnal Penelitian Politik, Vol. 10, No. 1, Juni 2013.

Romli, Lili, "Mekanisme Penyelesaian Konflik Partai Politik", terdapat dalam http:/ /lipi.go.id/berita/mekanisme-penyelesaian-konflik-partaipolitik/1394. Diakses tanggal 2 Juni 2017.

Setyodarmodjo, Soenarko, "Organisasi Partai Politik dan Demokrasi," Masyarakat, Kebudayaan dan Politik, Th XIII, No 1, Januari 2000. 


\section{Wawancara}

Hasil Wawancara dengan Djon Kibo salah seorang kader partai DPD Provinsi DIY pada tanggal 31-05-2016 di kantor wilayah Partai Golkar Provinsi DIY.

\section{Koran}

Prabowo, Dani, "Ini 8 Keputusan Mahkamah Partai Atasi Konflik Internal PPP”, Kompas, 13 Oktober 2014.

\section{Internet}

Hikmatul Fauziah, Ade, "Sikap Politik Partai Persatuan Pembanguan dalam Suksesi Kepemimpinan Negara Pada Pemilu 2014", terdapat dalam http:// repository.uinjkt.ac.id/dspace/bitstream/123456789/31365/1/Ade \%20Hikmatul\%20Fauziah.pdf, diakses tanggal 26 Mei 2017.

Muhammad, Djibril, "Penyelesaian Perpecahan Partai Harus Ideologis", diakses dari http://www.republika.co.id/ berita/nasional/politik/15 /03/16/nlb15g-penyelesaian-perpecahan-partai-harus-ideologis pada tanggal 27 September 2015.

Rizki Amylia, Dewi, dan Hananto Widodo, “Tinjauan Yuridis Pelaksanaan Pencabutan SK Menkumham Nomor: M.HH-01.AH.11.01 tentang Pengesahan Perubahan Ad/ Art Serta Komposisi Dan Personalia DPP Partai Golkar", terdapat dalam http://jurnalmahasiswa.unesa.ac.id/article /21173/43/article.pdf., diakses tanggal 27 Mei 2017. 